\title{
LONG-TERM DRIVERS OF WHEAT AND MAIZE COMMODITIES PRICES
}

Vilija ALEKNEVIČIENĖ, Institute of Economics, Accounting and Finance, Faculty of Economics and Management, Aleksandras Stulginskis University, Universiteto g. 10, LT-53361, Akademija, Kauno raj., Lithuania, vilija.alekneviciene@ asu.lt Asta BENDORAITYTE், Faculty of Economics and Management, Aleksandras Stulginskis University, Studentų g. 11, LT-53361 Akademija, Kauno raj., Lithuania, asta.bendoraityte@ asu.lt

In the last decades prices of agro-food commodities have a tendency of explosive growth. This increase quite usually is related with biofuels development. However, the prices of commodities are influenced by the set of different variables, i.e. supply and demand factors. In order to provide appropriate policy recommendations for agro-culture there is a need to evaluate the factors and their impact on agro-food commodities. This paper uses the multi regression model in order to analyze long-term drivers of annual world wheat and maize commodities prices. Analysis involves both demand (direct: biofuels production, commodities stock in the end of the period; indirect: the exchange rate, the interest rate, gross domestic product) and supply (price of crude oil) factors. The empirical results indicate that the main price drivers of wheat are crude oil prices, exchange rate and stock of wheat lagged one period. While the main maize price drivers are crude oil price and stock of maize lagged one period.

Keywords: long-term drivers, price of wheat commodities, price of maize commodities

\section{INTRODUCTION}

In the last decades prices of agro-food commodities have a tendency of explosive growth. In the period of 2000-2008 price of agro-food commodities have increased twice (World Bank, 2015). According to Rosegrant (et. al., 2006), Mitchell (2008), Rajagopal (et. al., 2009), Banse (et. al., 2008) and Collins (2008) this period of price growth quite often coincides with promotion of biofuel. So, increased biofuel production is usually considered as the most important factor on agro-food commodities prices growth. However, there are series of other factors which affect price of these commodities (e.g. impact of developing countries, changing dietary, growing energy needs and price, unfavorable weather conditions and speculations in agro-food commodities market). Thus, it is important to evaluate which factors have most significant impact on agro-food commodities prices in the long-term. This identification of the most important factors is an essential in order to provide an appropriate policy recommendation.

It is accepted, that production of biofuel divert limited arable land, labour and technical resources from alimentary to energy needs. Since agro-food commodities are used for meeting both of these needs, the demand of agro-cultural commodities increases. This leads to the rise of agro-food prices, e.g. the development of bio-ethanol should affect price of wheat and maize commodities, because bio-ethanol are produced from commodities which contain starch or sugar.

The analysis of commodities price factors enables us to understand the reasons of price growth and helps to control and manage these prices at national and regional levels. For example, past experience reveals, that export restrictions in separate countries determine the growth of global food prices. Although, these restrictions supposed to protect and provide exemptions for local agro-food commodities producers. This proves how important is to realize which factors form the national and global prices of agro-food commodities.

The problem of research - which drivers are most significant in long-term food prices movements.

The aim of the research is to identify long-term drivers of agro-food commodities prices and to evaluate their significance on global wheat and maize prices.

In order to achieve this, 3 tasks are set:

- To analyze and summarize the empirical studies concerning long-term drivers of agro-food commodities prices.

- To introduce methods used to evaluate the impact of factors on long-term agro-food commodities prices.

- To evaluate the impact of factors on long-term global wheat and maize prices.

The object of research - global wheat and maize commodities prices.

Research methods involve logical analysis and synthesis of scientific literature, statistical and econometric analysis.

Copyright (C) 2015 The Authors. Published by Aleksandras Stulginskis University. This is an open-access article distributed under the terms of the Creative Commons Attribution License (CC-BY 4.0), which permits unrestricted use, distribution, and reproduction in any medium, provided the original author and source are credited. 
There are three main chapters in the paper. In the first chapter the analysis and synthesis of previous research on the main factors of agro-food commodities prices is done. In the second chapter the reduced-form econometric model for the evaluation of the main long-term drivers of wheat and maize global prices is introduced as well as the analyzed variables and their expected impact on agro-food commodities prices are presented. In the third chapter the empirical research is done and the results are discussed. Finally, conclusions and the main insights about the analyzed problem are given.

\section{LITERATURE REVIEW}

Worldwide interest in agro-food commodities prices and it's drivers increased after rapid growth of agro-food prices in 2007-2008. In this period food and agro-food commodities price indexes have doubled comparing with price level in 2000. Researchers (Rosegrant et al., 2006; Mitchell, 2008; Baier et al., 2009; Chakravorty et al., 2010) analyze drivers, which could have influence on this significant increase of agro-food prices. One of the main factors which they used to explain the increase in agricultural and food prices was development of biofuel production and consumption. This interest in biofuels impact on agro-food commodities prices is easy to explain. Biofuels as alternative fuels were started to promote in EU by Biofuels Directive 2003/30 EC and in the United States by Renewable Fuel Standard (RFS), which was released in 2007. This period coincided with the growth of agro-food prices. Since the most popular biofuels - bio-ethanol and biodiesel, are made from the same raw materials as food, biofuels development directly increases demand for agricultural products, and directs the use of food commodities for non-food purposes. Effects of biofuel production also are seen through diversion of human capital, water and other resources from food needs satisfaction towards the energy sector. Thus increasing production of biofuels is linked to increased demand of these commodities and rising prices of agricultural production.

However, the scientists have different point of view evaluating the impact of biofuels on agro-food commodity prices, since their studies bring contradictory results. D. Mitchell (2008) states that 70-75 percent of agricultural products prices have increased due to expanded biofuel production and other factors caused by biofuel development: low raw food materials stocks, changed proportion of grown crops, speculative factors and an export bans. Contrarily, S. Baier et al. (2009) study reveals that the EU's promotion of biofuels production increased corn and soybean prices only by 3 percent. So the impact of biofuel development was insignificant.

It is important to highlight the fact that many previous studies examine only the last decade of agricultural and food prices in order to explain the period of the highest increase of agro-food prices in 2007-2008. Meanwhile, Baffes and Dennis (2013) analyzed long-term price drivers of six agro-food commodities: corn, wheat, rice, soybean and palm oil prices in the period 1960-2012. J. Baffes and A. Dennis (2013) notes that commodity price growth occurred in a period when most economies, particularly developing, experienced strong economic growth. In many countries fiscal expansion and loosened monetary policy led to a sharp rise in commodity prices. Depreciation of US dollar, which is the most widely used currency in international transactions, strengthened the demand and restricted the supply of non-US dollar operating producers and consumers. All of this has contributed to food price increases. Others frequently mentioned factors are the low level of investment in agro sector, insufficiently active investment fund, and geopolitical problems, which are particularly noticeable in the energy market. The result of Baffes and Dennis (2013) study reveals that prices of agro-food products are affected by stock to use ratio (except rice), crude oil prices and exchange rate. Crude oil price affects agro-food prices through direct effect on preparation of farmland, transportation, and at the same time, indirect through price of fertilizers. Usually, interest rates and income aren't significant factors for agro-food price movement.

Without J. Baffes and A. Dennis (2013) mentioned factors, prices of agricultural products have been exposed to high energy and chemical product prices, unusually frequent unfavorable weather conditions, and diversion of some agricultural products to biofuel production -- especially maize in the USA and oily products in Europe. This condition reduced the ratio of global stocks and total use to very low levels - like in 1970, during the crisis of oil prices. Finally, political actions, including an export ban and a high export tax implementation exacerbated food price rises (Baffes and Dennis 2013).

The study of B. Gourisse et al. (2011) identifies main fundamental factors, which have effect on agro-food prices: 1. Increasing world population and increasing income in developing countries affect demand of agro-food. There is a prognosis that up to 2050 world population will reach 8.9 billion inhabitants (United Nations, 2004). Meanwhile demand for food commodities growth 70-100 percent. So, this prognosis already is sufficient factor to make pressure for agro-food prices. Unless there will be some significant changes in food production, quality of storage and transportation nets in whole world, especially in developing and raising countries.

2. Price of agro-food products become more and more related with prices of crude oil. So, crude oil prices have direct impact on final product prices (e.g. through fuels and fertilize prices). Additionally, depending on agro-food commodities and fuel prices, production of biofuels can become profitably business (production of biofuels develops event without support of government) in separate OECD countries.

3. Impact of climate factor also have indisputable impact on agro-food price movements, in 2008 prices of wheat was affected by drought in Australia (this country is one of the biggest supplier of wheat). Later droughts and fires in Russia, apprehension about crop yield in Australia and Argentina, some negative prognosis about climate condition in USA determined strong reaction of market and, finally, rising agro-food commodities prices.

4. During the period of 2007-2008, some part of governments implemented protective politics (e.g. export prohibition or promotion of commodities storage) have direct and indirect impact on crises of food prices, increased amplitude of price movements and in some cases provoke price rise. There is estimation that without such of political decisions there won't be this kind of effects. 
D. Headey and S. Fan (2010) graphically depict agro-food price formation and its drivers through supply and demand factors (see. Figure 1) Together with supply and demand factors there are others macroeconomic variables which have impact on agro-food prices too. So, the groups of agricultural and food prices factors, suggested by D. Headey and S. Fan (2010), will be considered for the constructing the model.

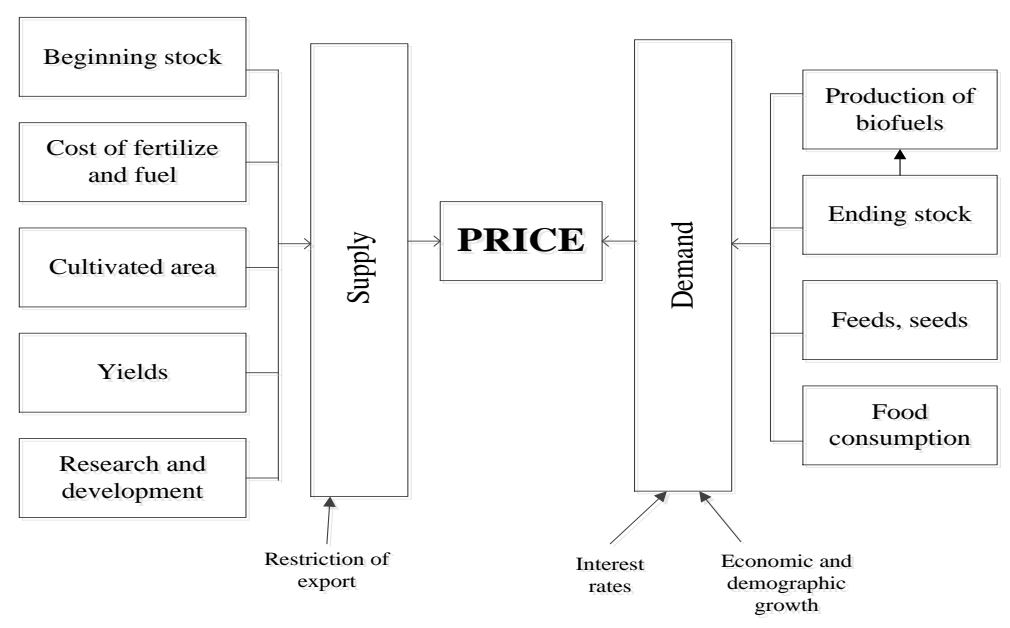

Source: adaptation of D. Headey and S. Fan, 2008

Figure 1. Prices of agricultural commodities formation

A. Rezitis and M. Sassi (2013) use structural time series model in order to analyze the movements of monthly food price index in 1992 - 2012 period. There data of price divided into trend, seasonal, cycle, fictional interventions and unpredictable components. Study results study revealed that movement of the prices best define by fixed level, seasonal, two stochastic cycles and two explicable variables: crude oil prices and real USA dollar exchange rate. Here as it is expected crude oil price have positive impact meanwhile exchange rates have negative impact. Prognosis of this study shows high and changeable agro-food prices in medium term periods.

Contrary results bring C. Benjamin et. al. (2009) study. In this research long-term relations connections between wheat and crude oil prices are define. These results reveal empirical evidence that crude oil price don't have significant influence on wheat prices.

Rezitis and M. Sassi (2013) generalize that the main problem is agro-food product stability reassurance. Researchers raise two questions. Firstly, what kind of effect (direct or inverse) has each factor on agro-food prices. Secondly, how strongly agro-food price movements are determined by structural changes and cyclicality.

Summarized results of literature review are represented in the Table 2.

Table 2. Main factors of agro-food commodities prices

\begin{tabular}{|c|c|c|c|}
\hline \multirow{2}{*}{ Study } & \multirow{2}{*}{ Supply factors } & \multicolumn{2}{|c|}{ Demand factors } \\
\hline & & Direct variables & Indirect macroeconomic variables \\
\hline Mitchell (2008) & Increase of energy cost & Production of biofuels & Exchange rate \\
\hline Baier et al. (2009) & Price of energy & Production of biofuels & Exchange rate \\
\hline Benjamin et al. (2009) & Price of crude oil & - & - \\
\hline Chakravorty et al. (2010) & $\begin{array}{l}\text { Cultivated area, } \\
\text { price of crude oil }\end{array}$ & $\begin{array}{l}\text { Income growth } \\
\text { production of biofuels }\end{array}$ & - \\
\hline Schaffnit-Chatterjee (2011) & $\begin{array}{l}\text { Weather conditions, } \\
\text { Price of crude oil }\end{array}$ & $\begin{array}{l}\text { Population growth, } \\
\text { income growth, } \\
\text { production of biofuels }\end{array}$ & $\begin{array}{l}\text { Inflation, } \\
\text { exchange rate, } \\
\text { Interest rate } \\
\end{array}$ \\
\hline Gourisse et al. (2011) & $\begin{array}{l}\text { Price of crude oil, } \\
\text { weather conditions }\end{array}$ & $\begin{array}{l}\text { Population growth, } \\
\text { income growth, } \\
\text { production of biofuels }\end{array}$ & (5) \\
\hline Hochman et al. (2012) & Price of energy & Production of biofuels & GDP, exchange rate \\
\hline Laborde et al. (2013) & $\begin{array}{l}\text { Yields, } \\
\text { cultivated areas, } \\
\text { food waste } \\
\end{array}$ & $\begin{array}{l}\text { Population growth, } \\
\text { income growth }\end{array}$ & Exchange rate \\
\hline Rezitis, Sassi (2013) & Price of crude oil & - & Exchange rate \\
\hline Baffes and Dennis (2013) & $\begin{array}{l}\text { Price of energy, } \\
\text { food stock }\end{array}$ & Increase of income level & $\begin{array}{l}\text { Exchange rate, } \\
\text { interest rate, inflation }\end{array}$ \\
\hline ULYSSES (2014) & $\begin{array}{l}\text { Price of crude oil, } \\
\text { yields }\end{array}$ & Production of biofuels & $\begin{array}{l}\text { Exchange rate, GDP, } \\
\text { price level }\end{array}$ \\
\hline Baffes, Etienne (2014) & $\begin{array}{l}\text { Cost of energy, } \\
\text { food stock }\end{array}$ & Income growth & - \\
\hline
\end{tabular}


To sum up, it is notable that mostly the researchers identify biofuels as one of the main factors, which have influence on agro-food prices. Population and increase of income are factors more commonly used to define demand factors on agro-food prices. Crude oil price is frequently identified as supply factor. USA exchange rate and interest rates are mostly analysed macroeconomics factors.

\section{MODEL}

In order to identify the log-term drivers of main agro-food prices, reduce-form model of price determination is used. This study is based on aggregate supply and demand comparison of analyzed commodities (wheat and maize). This helps identifying an equilibrium price as a function of agro-food sector and macroeconomic variables. The model is presented in the Formula 1. All variables used in the model are in the logarithm form.

$$
\begin{aligned}
\log \left(P_{t^{i}}\right)=\beta_{0} & +\beta_{1} \log \left(S T_{t-1}\right)+\beta_{2} \log \left(P_{t} \text { oIL }\right)+\beta_{3} \log \left(X R_{t}\right)+\beta_{4} \log \left(R_{t}\right) \\
& +\beta_{5} \log \left(G D P_{t}\right)+\beta_{6} \log \left(B I O E_{t}\right)+\varepsilon_{t}
\end{aligned}
$$

$P_{t^{i}}$ - nominal price of agro-food commodity $i$ in the long-term period $t$ ( $i=$ wheat and maize)

$S T_{t^{i}-1}$ - stock of commodity in time period $(t-1)$; lagged factor;

$P_{t}$ OIL - price crude oil in time period $t$;

$X R_{t}$ - exchange rate in time period $t$

$R_{t}$ - interest rate in time period $t$;

$G D P_{t}-$ gross domestic product in time period $t$;

$B I O E_{t}$ - bio ethanol production in time period $t$;

The expected impact of most analyzed factors is simply interpreted (see Table 3). Direct relation is expected between the prices of wheat and maize commodities and GDP, crude oil prices and production of bio- ethanol. When these variables increase, it is expected that wheat or maize prices increase too. And opposite, increased in stock of wheat and maize and exchange rate should decrease wheat and maize prices during the research period. Meanwhile the impact of interest rate can be dual: high interest rates can be related with low commodities prices. This is the case, when interest rates decrease current demand for agro-food commodities. Likewise, it is possible situation, when interest rates can change future expectations, and investment into agriculture. However, agro-food prices can growth when interest rate increases because there is increase in expected return for commodities storage.

Table 3. Variables used in the model and expected relations

\begin{tabular}{|c|c|c|c|c|}
\hline Variable & Abbreviation & Explanation of variable & Relation between variables & Data base \\
\hline Price of wheat & $P_{t^{W}}$ & Dependent variable & - & World Bank \\
\hline Price of maize & $P_{t^{M}}$ & Dependent variable & - & World Bank \\
\hline Stock of wheat, in the end of period & $S T_{t^{W}-1}$ & Independent variable & Inverse & $\begin{array}{c}\text { United States } \\
\text { Department of } \\
\text { Agriculture }\end{array}$ \\
\hline Stock of maize, in the end of period & $S T_{t^{M}-1}$ & Independent variable & Inverse & $\begin{array}{c}\text { United States } \\
\text { Department of } \\
\text { Agriculture }\end{array}$ \\
\hline Price of crude oil & $P_{t^{\text {OIL }}}$ & Independent variable & Direct & World Bank \\
\hline Exchange rate & $X R_{t}$ & Independent variable & Inverse & $\begin{array}{c}\text { Federal Reserve of } \\
\text { USA }\end{array}$ \\
\hline Interest rate & $R_{t}$ & Independent variable & Inverse/direct & $\begin{array}{c}\text { Internetional Monetary } \\
\text { Fund }\end{array}$ \\
\hline GDP & $G D P_{t}$ & Independent variable & Direct & World Bank \\
\hline Production of bio ethanol & $B I O E_{t}$ & Independent variable & Direct & $\begin{array}{c}\text { United States } \\
\text { Department of } \\
\text { Agriculture }\end{array}$ \\
\hline
\end{tabular}

Source: made by the authors

Prices of wheat and maize commodities are expressed as medium annual price in USA dollars per ton. Prices of crude oil are expressed as medium price of intermediate of Brent, Dubai, West Texas, USA dollars per bushel. Production of bio ethanol is delivered by United States Department of Agriculture. Exchange rate is delivered by Federal Reserve of USA dollar index comparing with 4 other currencies: euro, pound, yen, and USA dollar. Interest rates - 10 years USA government securities. World GDP is delivered by World Bank data base. The research period involves 1981-2014.

J. Baffes and X. Etienne (2014) apply stock to use ratio (S/U) lagged one period. These researchers estimate that even some of the factors are identified as crucial for evaluating agro-food commodities price movement, they don't have to be directly involved in the model. However, it is estimated that these factors are incorporated in the model indirectly through stock to use ratio. Diversion of agro-food commodities to production of biofuels increases 
consumption of these commodities and decreases stock. This determines lower stock to use ratio. Similarly, in their study weather conditions are revealed through stock to use ratio too. Also, this ratio explains the effect of increasing income, where growing (decreasing) income indicates increased (decreased) agricultural commodities consumption, because of changing dietary. People consume more meat and dairy products, which production use more agricultural commodities. In the limited period of time this equation would be correct especially in developing countries. Where conditional big part of the income is directed for alimentation expenditure and inhabitant feel the lack of food. But, in this research global price of wheat and maize prices are analyzed. So it is difficult agree with this S/U ratio interpretation. In it is commonly agreed that not all incremental income is directed for consumption, especially for food. (because larger and larger share of income is directed for saving).

\section{EMPIRICAL RESULTS OF THE STUDY}

Before the estimation of model, there is a need to evaluate stationary of all variables by applying unit root test. For this evaluation Augmented Dickey Fuller $(A D F)$ unit root test is employed. In order to determine stationary of the data ADF test two hypotheses:

$\mathrm{H} 0: \mathrm{a} 1=1$ (process is non-stationary).

$\mathrm{H} 1: \mathrm{a} 1<1$ (process is stationary).

The results of ADF test are presented in the Table 3. For every variable, we deny first hypothesis, and accept second one - our data are stationary. The parameters of data such as mean and dispersion are characterized by constancy in time. This means that analyzed data aren't accidental and can be used in this research and prognostication.

Table 3. Analysis of stationary using ADF unit root test

\begin{tabular}{|c|c|c|c|c|}
\hline \multirow{3}{*}{$\begin{array}{l}\text { Variable } \\
\text { Price of wheat }\end{array}$} & \multicolumn{4}{|c|}{ Augmented Dickey Fuller $(A D F)$ unit root test } \\
\hline & \multirow{2}{*}{$\begin{array}{c}\text { Process without trend } \\
-0,48 \\
\end{array}$} & Process with trend & \multicolumn{2}{|c|}{ First differences } \\
\hline & & $-1,92$ & $-5,43$ & $* * *$ \\
\hline Price of maize & $-1,40$ & $-2,13$ & $-4,74$ & $* * *$ \\
\hline Bio-ethanol production & $-0,22$ & $-2,08$ & $-4,99$ & $* * *$ \\
\hline Price of crude oil & $-0,34$ & $-2,19$ & $-3,54$ & $* * *$ \\
\hline GDP & 1,42 & $-3,75$ & $-4,42$ & $* * *$ \\
\hline Exchange rate & $-1,02$ & $-3,22$ & $-5,28$ & $* * *$ \\
\hline Interest rate & 0,12 & $-3,58$ & $-5,97$ & $* * *$ \\
\hline Stock of wheat, in the end of period & $-3,63$ & $-3,78$ & $-4,76$ & $* * *$ \\
\hline Stock of maize, in the end of period & $-2,22$ & $-1,92$ & $-4,73$ & $* * *$ \\
\hline
\end{tabular}

Significance level of stationarity* $=10 \%, * *=5 \%, * * *=1 \%$.

Source: made by the authors

After assurance stationary of data, all variables are used to make a multi regression model for drivers of long-term wheat prices. So we use 6 variables: production of bio-ethanol, GDP, price of crude oil, exchange rates, interest rates, stock of wheat in the end of period. However, it is seen that part of variables are characterized by multicollinearity. This mean, that variables are interdependent. This problem can't assure us about precisely identification of long-term drivers of wheat prices or their influence on wheat prices. Variance inflator factor (VIF) statistic enables us to identify multicollinearity. This factor is emerges from tolerance value, the bigger it is, the bigger interdependency. It is assessing:

- $\quad$ if $4<\mathrm{VIFj}<10$ - it is possible that variable $\mathrm{Xj}$ is multicollinearity (medium to strong);

- $\quad$ if $\mathrm{VIFj} \geq 10$ - variable $\mathrm{Xj}$ characterized as too multicollinear.

So, one by one multicollinear variables are eliminated. Highest interdependency has variables of bio-ethanol, GDP and interest rates. And three variables are suitable for our multi regression: price of crude oil, exchange rate of USA dollar and stock of wheat in the end of period. These variables are characterized as most significant long-term drivers of global wheat prices. The results of research are presented in the Table 4.

Table 4. Values of parameters in regression model of long term wheat world price

\begin{tabular}{|l|c|c|c|c|c|}
\hline \multicolumn{5}{|c|}{$\mathrm{R}=0.891 \mathrm{R}^{2}=0.794$ Std. error of the estimate: 0.06720} \\
\hline \multicolumn{1}{|c|}{ Variables } & $\mathrm{B}$ & Std. Error & Beta & t-statistic & Sig. \\
\hline Coeficient $\beta_{0}$ & - & 0.394 & 2.376 & 6.026 & 0.000 \\
Price of crude oil & 0.706 & 0.046 & 0.336 & 7.225 & 0.000 \\
Exchange rate & -0.287 & 0.272 & -0.778 & -2.861 & 0.008 \\
Stock of wheat in the end of period & -0.172 & 0.174 & -0.340 & -1.954 & 0.006 \\
\hline
\end{tabular}

$$
\text { Source: made by the authors }
$$

Determination coefficient R (0.891) demonstrates strong direct dependence between price of wheat and price of crude oil, stock of wheat in the end of period, and exchange rate of USA dollar. Determination coefficient $(\mathrm{R} 2=0,794)$ 
reveals that 79 percent of long-term wheat price dynamic we can explain influence of price of crude oil, stock of wheat in the end of period and exchange rate of USA dollar. These variables are statistically significant $(\mathrm{p}<0.05)$.

As it was expected we reach the following results: direct relation between growth of crude oil and wheat prices, and inverse relation between exchange rate, stock of wheat and price of wheat and wheat prices.

Equation of wheat price drivers and their impact can been written like this:

$$
\log \left(P_{t^{W}}\right)=2,376-0,34 \log \left(S T_{t^{W}}\right)+0,336 \log \left(P_{t} \text { oIL }\right)-0,778 \log \left(X R_{t}\right)
$$

Equation shows: 10 percent increase in crude oil prices influences the growth of long-term wheat prices by 3.36 percent. While 10 percent increase in exchange rates determines 7.78 decrease of wheat prices. Meanwhile, 10 percent increase in wheat stock determines 3.4 percent decrease of wheat prices. The results of our research are similar to Baffes and Etienne (2014) study in case of crude oil prices and exchange level.

Evaluating long-term impact of different variables on maize prices, 6 variables are included in the model: production of bio-ethanol, GDP, price of crude oil, exchange rate, interest rate, stock of maize in the end of period. The same procedure is carried out. After testing the multicollinearity, the bio-ethanol (VIF - 35.193) and GDP (VIF - 19.437) were eliminated out of model. Impact of remaining variables is represented in the Table 5.

Table 5. Values of parameters in regression model of long-term maize world prices

\begin{tabular}{|l|c|c|c|c|c|}
\hline \multicolumn{7}{|c|}{ Std. error of the estimate: 0.08463} & Beta & t-statistic & Sig. \\
\hline \multicolumn{1}{|c|}{ Variables } & B & Std. Error & $0.858 \mathrm{R}^{2}=0.737$ \\
\hline Coeficient $\beta_{0}$ & - & 0.338 & 2.107 & 6.229 & 0.000 \\
Price of crude oil & 0.746 & 0.076 & 0.388 & 5.077 & 0.000 \\
Exchange rate & -0.033 & 0.488 & -0.098 & -0.201 & 0.842 \\
Interest rate & 0.020 & 0.153 & 0.015 & 0.095 & 0.925 \\
Stock of maize, in the end of period & -.0277 & 0.073 & -0.191 & -2.610 & 0.014 \\
\hline
\end{tabular}

Source: made by the authors

As it is shown in the Table 5, determination coefficient $\mathrm{R}$ is 0.858 . It demonstrates strong direct dependence between price of maize and price of crude oil, stock of maize in the end of period.

Determination coefficient $\left(\mathrm{R}^{2}=0.737\right)$ reveals that 74 percent of long-term maize price movement can be explained by influence of crude oil price and maize stock in the end of period. Variables are statistically significant at level $\mathrm{p}<0.05$.

As it was expected growth of crude oil increases maize prices, decrease of exchange rate and stock of maize increase prices of maize.

Equation 3 gives the final estimation of the coefficients of maize prices.

$$
\log \left(P_{t^{M}}\right)=2,107-0,191 \log \left(S T_{t^{M}-1}\right)+0,388 \log \left(P_{t} \text { oIL }\right)
$$

Equation shows that 10 percent increase in crude oil prices determines long-term maize price growth by 3.88 percent. Meanwhile, 10 percent increase in maize stock in the end of period causes 1.91 percent decrease of maize prices. The results of our model are a bit different comparing with similar study of Baffes J. and Etienne X. (2014). We estimated stronger impact of crude oil price on maize prices.

\section{CONCLUSIONS}

The researchers identify three types of factors which affect agro-food commodities prices: supply, demand and macroeconomics variables. The last group involves growth of economics, exchange and interest rates. Meanwhile elements such as cruel oil and fertilize prices, area of arable land, crop yield and, finally, weather conditions have impact on supply of agro-food commodities. The demand of these commodities is influenced by population growth, increased income level and biofuel production. Despite the fact that biofuel and bio-ethanol is often identified as one of the main factor which has influence on agro-food commodities, this effect attains contradictory evaluation. Ordinarily, mandates of biofuels should affect demand of agro-food commodities, because share of these products is directed to meet energetic needs. So, demand of agro-food product increases.

In this study multi regression model is applied. It enables us to evaluate the impact of various long-term drivers of wheat and maize world prices. Analyzed variables represent all three categories of factors: demand, supply and macroeconomic. The results of research reveal that long-term wheat world prices are influenced by cruel oil price, exchange rate changes and stock of wheat with one period lag. Whereas cruel oil price changes and maize stock with one period lag have influence on maize price. The research shows that bio-ethanol does not have influence on wheat and maize world prices in the long period. 


\section{REFERENCES}

1. Baffes, J., Dennis, A. 2013. Long-term drivers of food prices. World Bank Policy Research Working Paper, (6455). http://dx.doi.org/10.1596/1813-9450-6455

2. Baffes, J., Etienne, X. L. 2014. Reconciling high food prices with Engel and Prebisch-Singer. In international conference "Food Price Volatility: Causes and Consequences. Available at: http://www.imf.org/external/np/seminars/eng/2014/food/pdf/baffes.pdf (accessed on 21/05/2015).

3. Baier, S., Clements, M., Griffiths, C., Ihrig, J. 2009. Biofuels Impact on Crop and Food Prices: Using an Interactive Spreadsheet, Board of Governors of the Federal Reserve System International Finance Discussion Papers, Number 967

4. Banse, M., Van Meijl, H., Tabeau, A., Woltjer, G. 2008. Impact of EU Biofuel Policies on World Agricultural and Food Markets, Agricultural Economics Research Institute (LEI), The Hague. Available at: https://www.gtap.agecon.purdue.edu/resources/download/3587.pdff (accessed on 10/03/2015).

5. Benjamin, C., Houee-Bigot, M., Tavera, C. 2009. What are the long term drivers of food prices? Investigating improvements in the accuracy of prediction intervals for the forecast of food prices. In Agricultural and Applied Economics Association Annual Meeting in Milwaukee, Wisconsin, pp. 26-28.

6. Chakravorty, U., Hubert, M. H., Moreaux, M., Nøstbakken, L. 2010. Do Biofuel Mandates Raise Food Prices? In AERE Annual Meeting, Ashville, NC, USA, pp. 3-5.

7. Collins, K. 2008. The Role of Biofuels and Other Factors in Increasing Farm and Food Prices, A Review of Recent Developments with a Focus on Feed Grain Markets and Market Prospects. Available at: http://www.globalbioenergy.org/uploads/media/0806 Keith Collins _The_Role_of_Biofuels_and_Other_Factors.pdff (accessed on 23/05/2015).

8. Gourisse B., Andrews S., Horstmann K. P. 2011. Regulation of Commodity Derivatives markets within MiFID Position limits and position management rules. Available at: $\underline{\mathrm{http}}: / / \mathrm{www} 2 . i s d a . o r g / a t t a c h m e n t / \mathrm{MzgzNg}==/ 201111$ positionlimitspositionmanagement.pdf (accessed on 21/05/2015).

9. Headey D., Fan Sh. 2008. Reflections on the Global Food Crises. How Did It Happen? How Has It Hurt? And How Can We Prevent the Next One? International Food Policy Research Institute. Washington, DC, USA, 2010.

10. Hochman, G., Kaplan, S., Rajagopal, D., Zilberman, D. 2012. Biofuel and Food-Commodity Prices. Agriculture, Vol. 2, Iss. 3, pp. 272-281. http://dx.doi.org/10.3390/agriculture2030272

11. Laborde, D., Tokgoz, S., Torero, M. 2013. Long-Term Drivers of Food and Nutrition Security. FOODSECURE working paper no. 06 February 2013. Available at:

http://www3.lei.wur.nl/FoodSecurePublications/06_Laborde\%20Tokgoz\%20Torero_FNS\%20drivers.pdf (accessed on 21/05/2015).

12. Mitchell, D. 2008. A note on rising food prices. Policy Research Working Paper No. 4682.Washington, DC, World Bank. http://dx.doi.org/10.1596/1813-9450-4682

13. Rajagopal, D., Sexton, S., Hochman, G., Roland-Holst, D., Zilberman, D. 2009. Model estimates food-versus-biofuel trade-off. University of California Agriculture, Vol. 63, No. 4, pp. 199-201. http://dx.doi.org/10.3733/ca.v063n04p199

14. Rezitis N., Sassi, M. 2013. Commodity Food Prices: Review and Empirics. Economics Research International, Vol. 2013,15 p. http://dx.doi.org/10.1155/2013/694507

15. Schaffnit-Chatterjee, C., Schneider, S., Peter, M., Mayer, T. 2011. Where are food prices heading. Deutsche Bank Research. Available at: http://www.dbresearch.eu/PROD/DBR_INTERNET_DEPROD/PROD0000000000270746/Where+are+food+prices+heading\%3F+Short-term+drivers,+trends+and+implications.PDF (accessed on 21/05/2015).

16. Ulysses 2014. Long term drivers of food markets variability and uncertainty. Policy Briefing No 02. Available at: http://www.fp7ulysses.eu/publications/ULYSSES\%20Policy\%20Brief\%202 Long\%20term\%20drivers\%20of\%20food\%20markets\%20variabili ty\%20and\%20uncertainty.pdf (accessed on 21/05/2015).

17. United Nations. Dept. Of Economic 2004. World population to 2300. Vol. 236. United Nations Publications. 